\title{
Artificial Intelligence: Machine Translation Accuracy in Translating French-Indonesian Culinary Texts
}

\author{
Muhammad Hasyim ${ }^{1}$ \\ Hasanuddin University \\ French Literature Study Program \\ Cultural Science Faculty, Makassar, Indonesia
}

\author{
Firman Saleh ${ }^{2}$ \\ Hasanuddin University \\ Local Language Study Program \\ Cultural Science Faculty, Makassar, Indonesia
}

\author{
Rudy Yusuf ${ }^{3}$ \\ Hasanuddin University \\ Japanese Language Study Program \\ Cultural Science Faculty, Makassar, Indonesia \\ Asriani Abbas ${ }^{4}$ \\ Hasanuddin University \\ Indonesian Literature Study Program \\ Cultural Science Faculty, Makassar, Indonesia
}

\begin{abstract}
The use of machine translation as artificial intelligence (AI) keeps increasing and the world's most popular translation tool is Google Translate (GT). This tool is not merely used for the benefits of learning and obtaining information from foreign languages through translation but has also been used as a medium of interaction and communication in hospitals, airports and shopping centers. This paper aims to explore machine translation accuracy in translating French-Indonesian culinary texts (recipes). The samples of culinary text were taken from the internet. The research results show that the semiotic model of machine translation in GT is the translation from the signifier (forms) of the source language to the signifier (forms) of the target language by emphasizing the equivalence of the concept (signified) of the source language and the target language. GT aids to translate the existing French-Indonesian culinary text concepts through words, phrases and sentences. A problem encountered in machine translation for culinary texts is a cultural equivalence. GT machine translation cannot accurately identify the cultural context of the source language and the target language, so the results are in the form of a literal translation. However, the accuracy of GT can be improved by refining the translation of cultural equivalents through words, phrases and sentences from one language to another.
\end{abstract}

Keywords-Machine translation; Google translation; accuracy; culinary texts; artificial intelligence

\section{INTRODUCTION}

The information age has changed the social order of the world. Its presence allows global society to be able to interconnect countries with different language backgrounds. Language barriers are not a challenge in interacting and communicating between individuals and groups. Translation applications help people communicate easily. This can be seen in communication through social media, for example, Facebook and Twitter.

Sergey Brin, the co-founder of Google, received a fan letter from Korea. Brin was very curious about the contents of the letter which was written in Korean. But Brin doesn't speak. He ran the message through GT that he had. The letter was translated into, "the sliced raw fish shoes it wishes. Google green union thing” [1]. From that moment on, he realized the importance of machine translation (applications) which aids people to communicate with each other from various parts of the world. Brin also developed a GT tool that can not only be used in the Windows version but also in the Android version.

With the advancement of translation applications, machine translation can match translation done by humans. Based on a survey conducted by Google in 2016, GT can perform translations in various levels of accuracy that are equivalent to human translators, for example from Spanish, Chinese and French to English and vice versa GT is believed to have very high accuracy results in translating English to Spanish, French, Chinese, or vice versa from these respective languages to English. Also, Google asked bilingual people to compare the output of Google machine translation with GMNT (Google Neural Machine Translation) technology and human translation. The sentences used for translation example were taken randomly from Wikipedia or news article. On a scale of 0 to 6 , the GMNT machine-scored an average of 5.43 or only a slight difference from the human translation score of 5.55. Google concluded that the new version of Google translation (GMNT) is believed to be 64 to 87 per cent more accurate than the previous engine (PBMT). It means that the new version of GT has a high level of accuracy that matches the human reference translation [2].

With translation applications capabilities that can match human translation, the use of translation applications (machine) has increased. Based on Google data, 600 million people are using the GT application. With 90 per cent of users are outside the US USA [3]. A study showed that because limited English language proficiency (LEP) is common in emergency patients in Spanish hospitals and many hospitals do not have formal written translations, many providers use automatic translation software, such as GT. A recent study utilizing professional translators to evaluate machine translation outputs in Spanish and Chinese showed that GT has a very high level of accuracy. Google Translate allows hospital staff and patients to communicate with each other [4]. 
Indonesia itself is the top ten most countries users of GT in the world. The growth of GT users in Indonesia is considered very high. Each year, the growth of these machine translation users in Indonesia reaches more than 300 per cent on mobile devices and 94 per cent on desktop web. Indonesians use GT to read articles or chat [5]. In college learning activities, GT is used as a learning medium for translating foreign news items [6]. Although use of Google translate in Indonesia has been widely used as a communication medium, there has not been much research on the accuracy of the outputs of GT from Indonesia into English and so on. This paper will examine the accuracy of GT in translating French-Indonesian culinary texts (recipes) from a semiotic perspective.

There has been many studies on translation, among others, translation accuracy using machine translation [7]; [4]; [8], times in novels translation [9], equivalence in translation [10], ideology in translation [11] and [12], gender-specific translation [13], metaphor translation [14] and errors in translation [15].

The main issue that has always been the focus of translation study is the transfer of messages (meaning) from the source language to the target language. The message is information conveyed from the source language and transferred to another language. The readers in the source language have the same understanding of the information conveyed to the target language readers. Semiotically, the message (information) is a signifier, and the meaning of the message generated by the message is a sign [16]. Information messages are signs formed from the relationship between the signified and signifier physically generated (media) by the sender (a person, author or device) to the recipient.

The role of the translator (human) is to transfer information messages to the target language acquired by the translator. The role of the translator is how to make the target language reader understand the information message being transferred. The recipient (reader) gets direct information (message) conveyed by the translator. Whatever is conveyed by the translator as the receiver and the sender will be accepted by the reader as the receiver. This process is called interlingual translation [17]. The readers can understand information messages based on the meaning of the message from the translator and readers do not have direct communication with the sender (author) of the source language.

In the context of machine translation with information technology, the translator in question is Artificial Intelligence (AI) which refers to a simulation of human intelligence in a machine programmed to think like humans and imitate their actions. Machine translation or translation applications are AI which has messages as translators that replace humans who have the role of diverting information messages from the source language to various other languages that have been provided by machine translators [8]. The machine translator already has a database of vocabulary and grammar from one language to another. Humans as application users run translation machines by entering information messages as the source language and translated into the target language.
The issue that will be discussed in this paper is how the process of machine translation from one source language to another. The author will discuss it using a semiotic perspective. Questions related to machine translation are how accurate is the machine translator from French to Indonesian. The analytical data is French culinary texts (recipes) retrieved from the internet.

\section{MaChine TRANSLATION AND SEMIOTICS}

The translation is an activity of transferring information messages from the source language to the target language. The focus of translation activities is to transfer information messages to another language acquired by the recipient (reader). The main objective of translation activities is how the target language reader understands the message being transferred. Catford [18] defines translation as the process of changing text from one language to another. Catford emphasizes translation activities on text transfer. Nida and Taber [19] states, "Translating consist in producing in the receptor language the closest natural equivalent to the message of the source language, first in meaning and secondly in style". This definition focuses on how to find the closest equivalent of the receiving language to the source language. Larson [20] defines translation by re-expressing the same meaning using lexicons and grammatical structures that are appropriate in the target language and cultural context. Larson emphasized translation activities based on meaning. According to him, translation is a transfer of meaning from the source language to the target language. Meaning is more important because it cannot be changed, while form may change.

Machine translation (MT) is a translation activity using computer software to translate verbal text (information messages) from one language to another. MT is a branch of computational linguistics that studies the use of computer software in translation activities. At a basic level, MT performs the simple substitution of words, phrases and grammar from one language to another. Online-based machine translation systems use machine learning technologies to translate large amounts of text to and from supported languages. The MT service translates text from the source language into different languages.

In the semiotic perspective, information messages conveyed in verbal language are symbols, which are built on the elements of signifier and signified. A signifier is a physical record of an information message in certain media and a signified is a concept generated by a signifier (a physical record of an information message). The semiotic translation is a significant transfer activity [21]. MT is an activity of transferring signs (verbal language). A signifier is a physical record of an information message in the source language and a signified is the concept of a physical record of an information message. The transfer activity in MT is to transfer the concept (signified) of the physical record of information messages from the source language into a signifier, a physical record of information messages into the target language. Signifier in the target language of the concept transfer activity as signifier from the source language. So, the concept of an information 
message as a signified in the source language has the same concept as a signified in the target language.

The recipients (readers) get direct information messages conveyed by MT. Anything that the machine translator transferred will be received by the reader as an information message in the target language. The concept of information messages as signified of the source language is transferred by using the target language signifier. Concepts that are transferred by machine translators semiotically use other language codes as a signifier.

The concept (signified) has universal properties in all languages. The signifier differentiates between one language and another by using the same concept. In a semiotic perspective, translation emphasizes the signified (concept). When we refer to the concept, something that is signified, then the concept of 'holiness', the signifier in English is 'horse', in Indonesian it is 'horse', and in French, 'cheval' and so on. The translation is the transfer of signifier from the source language to the original language based on the concept that is signified.

\section{RESEARCH METHOD}

The study used qualitatively. The research method used descriptive using qualitative analysis [22]. Semiotics is the theoretical framework for answering research problems. The author uses a semiotic model to examine the accuracy of MT (Google translate). The research object is culinary texts (recipes) taken from online media in French and GT is used to translate French text into Indonesian. The sample was culinary texts (cooking recipes). The writer chose one recipe text (pumpkin soup) which familiar in Indonesian culture. Thus, the primary data is the French culinary text retrieved from the internet and the translated text using GT.

The online text data analysis procedure is entering primary data (culinary text) in the source text column (option in French). Then, the writer chose Indonesian as the target language. After the source text data is in Google translate the application, then the translate button was pressed. The author made a table of the translation outputs consisting of two columns. The first column is the source text and the second column is the translated text. The table of translation output is used as the main data for analysis.

A semiotic model (signifier-signified-signifier) was used to assess the accuracy of translation with GT. The author analyzes the source text signifier and target text signifier and analyzes the concepts of equivalence (signified) in the target language (Indonesian).

\section{RESULTS AND DISCUSSION}

\section{A. Culinary Text Translation (Food Recipe)}

Source Texte (French): Soupe au potiron (Signifier/form) Ingrédients

- $1 \mathrm{~kg}$ de potiron

- 300 g de carotte

- 200 g d'oignon

- 200 g de poireau
- Beurre

- 3 gousses d'ail

- 1 bouquet garni

- $40 \mathrm{cl}$ de crème fraîche

- Sel

Préparation

Temps Total: $1 \mathrm{~h} 25$

Préparation: 25 min

Cuisson: $1 \mathrm{~h}$

1) Tailler les légumes en gros dés. Les faire suer dans le beurre.

2) Mouiller avec 1,5 l d'eau. Ajouter l'ail écrasé et le bouquet garni. Cuire 1 heure.

3) Passer au moulin à légume ou au mixer. Ajouter la crème fraîche, et servir chaud.

Target Texte (Indonesien): Sup Labu (Pumpkin soup/signifier/form)

Bahan (Ingredients):

- $1 \mathrm{~kg}$ labu (1 kg of pumpkin)

- 300 g wortel (300 g of carrot)

- 200 g bawang bombay (200 g of onion)

- 200 g daun bawang (200 g of leek)

- Mentega (butter)

- 3 siung bawang putih (3 cloves of garlic)

- 1 karangan bunga garni (1 bouquet garni)

- $40 \mathrm{cl}$ krim segar (1 bouquet garni)

- $\operatorname{Garam}$ (salt)

Meaning-Signified (concept):

1) In the text title section, the name of the dish can be identified as the translation outputs from Google Translate have the same equivalent in the Indonesian text. This means that Google translate uses the same concept (marker) for French and Indonesian.

2) Likewise, the ingredients translation for making pumpkin soup. Google Translate can translate using equivalents in Indonesian. Thus, Google translate uses the concept as the same marker in French as the source language and Indonesian as the target language.

3) The same thing goes for translating pumpkin soup cooking preparations. Google translate can divert informational messages with the same equivalence in Indonesian as the target language. Google translate can translate concepts (markers) to produce meanings that are equivalent to the source language. 


\section{B. Google Translate: Translation Equivalent}

Translation equivalent is the equivalence of source text with target text [10]. Meanwhile, Liu argues [23] that equivalence is a relationship between words or phrases from two or more languages that have the same meaning. The definition of equivalence can be strengthened by Russell's statement (1959) that no one can understand the word 'cheese' unless he has non-linguistic knowledge about cheese [24]. Russel's opinion shows that the word 'cheese' as a marker in English cannot be understood if it is not associated with cheese as an external object, which then becomes a sign in one's mind. People cannot understand a word as a signifier, the word 'cheese' if the word is not associated with something signified, Russel calls it the term non-linguistic acquaintance. So, something signified (concept) is outside the sign itself (signifier). Jacobson [25] argues that there is no sign (signatum) without a signifier (signum).

Catford [18] provides a different explanation of equivalence. According to him, translation equivalent activities are rarely found in the target language. One factor is the problem of grammatical differences, for example, demonstrative translation. The source language and target language can have equivalences when they are exchanged in certain situations. For example, the English demonstrative word, 'this' (singular), 'this book' and the plural "these", these books are translated in Indonesian into the demonstrative word 'ini' (this) which means singular and Indonesian does not acknowledge plural demonstrative words. The plural demonstrative equivalence can be exchanged in other situations using the plural noun, namely 'these books' (these books). In Indonesian, the plural in demonstrative is the noun, while in English, the word demonstrative and noun. Concerning Catford's opinion, translation equivalent is a transfer not based on meaning but based on the exchange of situations from the source language to the target language.

Equivalence in MT (GT) emphasizes the concept (signified) in the source language and target language. The translation process is the transfer of the form (signifier) from the source language to the form (signifier) of the target language using the same concept as the equivalent. So, the translation equivalent model in culinary texts is signifier 1 (source language) - signified - signifier 2 (target language). GT can translate words, phrases and sentences denotatively which emphasizes the equivalence of concepts between the source language and the target language. We can take the example in Table I from the text of the recipe for pumpkin soup (French to Indonesian).

Likewise, the conceptual equivalence of sentences. As an example, in the culinary text. GT translates sentences from the source language to the target language by emphasizing the equivalence of concepts (signified).

The equivalence of concept in sentences on Google translate:

1) Tailler les légumes en gros dés. Les faire suer dans le beurre. \ Potong sayuran menjadi kubus besar. Keringkan dengan mentega (Cut the vegetables into large cubes. Sweat them in the butter).
2) Mouiller avec 1,5 l d'eau. Ajouter l'ail écrasé et le bouquet garni. Cuire 1 heure. Basahi dengan 1,5 liter air. Tambahkan bawang putih yang dihancurkan dan karangan bunga. Masak selama 1 jam. (Wet with $1.5 \mathrm{l}$ of water. Add the crushed garlic and the bouquet garni. Cook for 1 hour).

3) Passer au moulin à légume ou au mixer. Ajouter la crème fraîche, et servir chaud. Lewatkan mesin penggiling sayuran atau blender. Tambahkan krim segar dan sajikan panas (Pass through a vegetable mill or a blender. Add the crème fraîche, and serve hot).

The semiotic model in the translation of equivalence of concepts in machine translation (GT) is Signifier (form) 1 in the source language - Signified (concept) - Signifier (form) 2 in the target language. GT transfers the form from the source language to the target language with the same concept (signified) as the conceptual equivalent.

TABLE I. EquiVALENCE OF CONCEPTS IN GOOGLE TRANSLATE

\begin{tabular}{|l|l|}
\hline $\begin{array}{l}\text { Source text (French) } \\
\text { Signifier (form) }\end{array}$ & $\begin{array}{l}\text { Target text (Indonesian) } \\
\text { Signifier (form) }\end{array}$ \\
\hline SouPE Au POTIRON & Sup Labu (Pumpkin soup) \\
& -1 kg labu (1 kg of pumpkin) \\
- $1 \mathrm{~kg}$ de potiron & $-300 \mathrm{~g}$ wortel (300 g of carrot) \\
- $300 \mathrm{~g}$ de carotte & $-200 \mathrm{~g}$ bawang bombay (200 g of onion) \\
- $200 \mathrm{~g}$ d'oignon & $-200 \mathrm{~g}$ daun bawang (200 g of leek) \\
- 200 g de poireau & - Mentega (butter) \\
- Beurre & -3 siung bawang putih (3 cloves of \\
- 3 gousses d'ail & garlic) \\
- 1 bouquet garni & -1 karangan bunga garni (1 bouquet \\
- 40 cl de crème fraîche & garni) \\
- Sel & -40 cl krim segar (1 bouquet garni) \\
& - Garam (salt) \\
\hline
\end{tabular}

C. The Issue of Cultural Translation in Machine Translation (Google Translate)

The issue found in MT (GT) is a cultural equivalence. Can GT know the culture of the source language and target language culture and how to differentiate the translation of words, phrases, sentences and culture? Previously, it has been explained that GT can translate words, phrases and sentences with the equivalent concept and denotation meaning. This means that the GT application has compiled a database of words, phrases and sentence grammar in the GT electronic dictionary. The issue found in machine translation is cultural.

One of the definitions of culture that always becomes an issue in translation is the way of life, whose manifestation is seen in the form of behaviour and the results are visible materially, which is obtained through the process of habituation and learning in society and passed from generation to generation. Hoed [9] states that culture is unique to certain communities and its mastery is through a process of habituation and learning from generation to generation. Because it is unique to society, no culture is the same. The concept of translation in culture is the transfer of cultural equivalents from the source language into the target language. An example of an equivalent French culinary culture is the word 'cuillère à café' (coffee spoon) which has the Indonesian equivalent of 'teaspoon'. French people have the habit of using 
a small spoon that is used to stir coffee drinks with the term 'cuillère à café'. Meanwhile, Indonesian people have the habit of using the word 'teaspoon' to stir tea, coffee, etc. French culture acknowledges the term cuillere a café for a small spoon that is usually used for drinking (coffee) and Indonesian culture acknowledges the term teaspoon used for tea drinks.

MT such as GT cannot translate cultural equivalents from the source language to the target language. In the text of French recipes above, there are several cases of cultural translation. For example, the sentences (1) mouiller avec 1,5 l d'eau (wet with $1.5 \mathrm{l}$ of water) and (2) ajouter le bouquet garni (add the bouquet garni), (3) passer au moulin à légume ou au mixer (pass through a vegetable mill or a blender). Sentence 1 translated into Indonesian becomes wet with 1.5 litres of water. The context of the sentence referred to in Indonesian in the sentence is to pour 1.5 litres into the container (poor water into ....) which already contains pumpkin soup ingredients. The word mouiller according to the dictionary means to wet (wet). But in the context of this sentence, it is put, add water into the container. Indonesian culture (point of view) to put water in a container, for example, a pot is to use the word pour, add instead of wetting for the context of adding water in a container. Sentence 2 ajouter le bouget garni translates to add a wreath. The general term used in Indonesian culture in a culinary context is the word bouquet garni (the name for several spices tied together to add flavour to the broth). So, sentence 2 should be translated to add bouquet garni (add the bouquet garni). The term bouquet garni was absorbed from English and became a term in the culinary field in Indonesian. Sentence 3 Passer au moulin à légume ou au mixer translates to skip through a vegetable mill or a blender. The context in Indonesian culture in the sentence is to mix the ingredients into a vegetable grinder or mixer (mix the ingredients into a vegetable grinder or mixer). The word passer (verb) means to miss. However, the Indonesian cultural context referred to in this sentence is mixing pumpkin soup ingredients into a mixer. Indonesian culture does not use the term passing the ingredients into a mixer, but instead mix the ingredients into a mixer (mix the ingredients into a vegetable grinder or mixer).

The different (cultural) perspective between the two languages (source and target) cannot be acknowledged by MT in culinary texts (recipes). MT has not been able to completely transfer the cultural equivalence from the source language to the target language. Thus, in the perspective of semiotics, the signifier is a form of the source language and signified is a cultural meaning or concept from the source language to the target language. In translation activities, the first signifier as a source is changed to the second signifier as the target language (Indonesian) and the signified (concept) is a cultural equivalence.

GT is a translation tool that can certainly add to the cultural equivalence database of the various translation cases found. By updating translation engine databases such as GT which can include additional vocabulary, phrases, grammar and cultural equivalences, machine translators can improve the accuracy of translation from one language to another. Along with the increasing users of translation machines like GT, GT is not merely used as a translation application but has become a medium of communication between individuals, groups and organizations. Various machine translators have been provided in various public facilities, such as hospitals for communication services between hospital staff and patients, supermarkets, airports, etc.

\section{CONCLUSION}

Online machine translator, GT has become a translator application used all over the world. This shows the enormous benefits of this translation application. The function of the machine translator GT is not merely a translation application to obtain information from foreign languages, but this application has served as a medium of interaction and communication in public facilities, for example in hospitals, airports and shopping centres. The conclusion of the research on the accuracy of GT as machine translation with a semiotic perspective on French-Indonesian culinary texts in this paper is that GT uses the semiotic model of machine translation from the signifier (form) of the source language to the signifier (form) of the target language by emphasizing the equivalence of the concept (signified) source language and target language. GT can accurately translate the corresponding French-Indonesian culinary text concepts using words, phrases and sentences. The machine translator GT has encountered problems with translating cultural equivalents in French and Indonesian culinary texts. GT has not been able to accurately identify the cultural context of the source language and target language, so the results are in the form of a literal translation.

\section{REFERENCES}

[1] Zainuddin Ahmad. Kelahiran Mesin Penerjemah dan Masa Depan Google Translate, in https://tirto.id/cxS2, 2017.

[2] Widiatanto, Yoga Hastyadi. Mesin Penerjemah Makin Mirip Manusia in https://tekno.kompas.com/, 2016.

[3] Pertiwi, W. K. 2018. Pengguna Google Translate Melonjak Selama Piala Dunia 2018" in https://www.kompas.com/, 2018.

[4] Kreger, V., Aintablian, H., Diamond, L., Taira, R.B. Google Translate as a Tool for Emergency Department Discharge Instructions? Not So Fast! Annals of Emergency Medicine, 74, (4), Supplement, S5-S6, 2019.

[5] Jumatulaini. Analisis Keakuratan Hasil Penerjemahan Google Translate dengan Menggunakan Metode Back Translation. Alsuniyat: Jurnal Penelitian Bahasa, Sastra, dan Budaya Arab, 3 (1), 2020, pp.77-87.

[6] Al-Ayubi, M. Shalehuddin. Utilization Of Google Translation As A Learning Medium At Foreign News Text Translation. Jurnal Teknodik, 21 (2), 2017, pp.155-166.

[7] Groves, Michael, Mundt, Klaus. Friend or foe? Google Translate in language for academic purposes. English for Specific Purposes, 37, 2015, pp.112-121.

[8] Stapleton, P., Ka Kin, B.L. Assessing the accuracy and teachers'impressions of GoogleTranslate: A study of primary L2 writers in Hong Kong. English for Specific Purposes, 56, 2019, pp.18-34.

[9] Hoed, Benny. Kala dalam Novel: Fungsi dan Penerjemahannya. sebuah kajian tentang penerjemahan Perancis-Indonesia. Yogyakarta, Gadjah Mada University Press, 1992.

[10] Panou, Despoina. Equivalence in Translation Theories: A Critical Evaluation. Theory and Practice in Language Studies. 3(1), 2013, pp.16.

[11] Valerio, Anna. Translation and ideology: a critical reading. Procedia Social and Behavioral Sciences. 70, 2013. pp.986 - 996.

[12] Kuswarini, Prasuri. A Shift of Ideology in the Translation of Karl May's Work Und Friede auf Erden! into the Indonesian Language. International Journal of Comparative Literature \& Translation Studies. 2 (3), 2014, pp.42-49.

[13] Hernández, Daniel Gallego, Igualada, Miguel Tolosa et Masseau, Paola. Traduction de genres économiques de l'espagnol vers l'allemand, le 
français et l'anglais et vice-versa. Enquête auprès d'entreprises exportatrices. Meta.63 (1), 2018, pp.30-46.

[14] Elena, Burmakova \& Marugina, I. Nadezda. Cognitive Approach to Metaphor Translation in Literary Discourse. Procedia - Social and Behavioral Sciences. 154, 2014, pp.527-533.

[15] Wongranu, Pattanapong. Errors in translation made by English major students: A study on types and causes. Kasetsart Journal of Social Sciences. 38, 2017, pp.117-122.

[16] Danesi, Marcel. (2010). Pengantar Memahami Semiotika Media. Jogyakarta, Jalasutra, 2010.

[17] Hasyim, M., Nursidah,, Hasjim, M. Online advertising: How the consumer goods speaks to women. Opcion, 35 (89), 2019, pp.826-845.

[18] Catford, J.C. A Linguistic Theory of Translation. Oxford University Press, 1978.

[19] Nida E.A., \& Taber C.R. The theory and practice of translation. Leiden, E.J. Brill, 1982.
[20] Larson, M.L. Meaning Based Translation: A Guide to Cross-Language Equivalence. Lanham \& London, University Press of Amerika, 1989.

[21] Hasyim, M., Arafah, B., Kuswarini, P. The new Toraja destination: Adding value 'Toraja coffee' of the sustainable tourism development. IOP Conference Series: Earth and Environmental Science, 2020, 575(1), 012072, 2020.

[22] Teng, M.B.A., Hasyim, M. The philosophy of kajaolaliddong: A basic pattern of life and culture in bugis and makassar. Systematic Reviews in Pharmacy, 11(12), 2020, pp.1548-1552.

[23] Liu, Lixiang. Partial equivalences in bilingual dictionaries: Classification, causes and compensations. Lingua, 214, 2018, pp.11-27.

[24] Russell, Bertrand. Logical positivism. Revue Internationale de Philosophie, 1959.

[25] Jakobson, Roman. On linguistic aspects of translation. In: Venuti, L. (Ed.), The Translation Studies Reader. 3rd ed. Routledge, London/New York, 2012, pp. 126-131. 